\title{
PENGARUH EXPERIENTIAL MARKETING DAN KUALITAS PELAYANAN TERHADAP LOYALITAS PELANGGAN RUMAH MAKAN ABENG 38
}

\author{
Vinna Angelia ${ }^{1}$, Sri Rezeki ${ }^{2}$ \\ ${ }^{1}$ STIE Eka Prasetya, Medan,Indonesia \\ ${ }^{1}$ STIE Eka Prasetya, Medan,Indonesia \\ v1nnaangelia.va@gmail.com
}

\begin{abstract}
The objective of the study is to identify the effect of experiential marketing on customer loyalty in Rumah Makan Abeng 38, identify the effect of service quality on customer loyalty in Rumah Makan Abeng 38, and identify the effect of experiential marketing and service quality on customer loyalty in Rumah Makan Abeng 38. The research methodology is descriptive quantitative method, analysis in this study is at Rumah Makan Abeng 38 and it's observation unit are customers of Rumah Abeng 38. The population in this study are customers of Rumah Makan Abeng 38 as many as 5894 respondents. The technique of determining by number of samples used in this study is Slovin formula and amount used 98 respondents. Coefficient of determination test results (R2) shows that of Customer Loyalty is influences by Experiential Marketing and Service Quality, while the remaining is influence of other factors or variable out of the observation like Price, Product Quality, Customer Satisfaction.
\end{abstract}

Keywords : Customer Loyalty, Experiential Marketing, Service Quality

\begin{abstract}
ABSTRAK
Penelitian ini bertujuan untuk mengetahui pengaruh experiential marketing terhadap loyalitas pelanggan pada Rumah Makan Abeng 38, mengetahui pengaruh kualitas pelayanan terhadap loyalitas pelanggan pada Rumah Makan Abeng 38, dan mengetahui pengaruh experiential marketing dan kualitas pelayanan terhadap loyalitas pelanggan pada Rumah Makan Abeng 38. Metodologi penelitian yang digunakan adalah metode deskriptif kuantitatif, unit analisis dalam penelitian ini adalah Rumah Makan Abeng 38 serta unit observasinya adalah pelanggan Rumah Makan Abeng 38. Populasi dalam penelitian ini adalah pelanggan yang makan di Rumah Makan Abeng 38 pada tahun 2018 sebanyak 5894 pelanggan. Hasil penelitian secara parsial menunjukkan bahwa experiential marketing berpengaruh positif dan signifikan terhadap loyalitas pelanggan pada Rumah Makan Abeng 38 dan
\end{abstract}


kualitas pelayanan berpengaruh positif dan signifikan terhadap loyalitas pelanggan pada Rumah Makan Abeng 38. Secara simultan, experiential marketing dan kualitas pelayanan secara simultan berpengaruh positif dan signifikan terhadap loyalitas pelanggan pada Rumah Makan Abeng 38.

Kata Kunci : Experiential Marketing, Kualitas Pelayanan, Loyalitas Pelanggan

\section{1) PENDAHULUAN}

Dalam menghadapi persaingan bisnis yang semakin ketat perusahaan berupaya untuk mempertahankan pelanggan lama dan mencari pelanggan baru yang potensial karena pelanggan merupakan sumber pendapatan perusahaan yang mempengaruhi keberlangsungan usahanya. Rumah Makan Abeng 38 merupakan rumah makan Chinese Food yang berada di jalan Bawean No. 38 Gang Buntu, Medan. Rumah makan ini memiliki menu makanan andalannya seperti Capchai, Khau Bak, Ayam Timah, dan Taucho Udang.

Menurut pengamatan peneliti pendekatan Experiential Marketing yang diterapkan diketahui perusahaan belum berhasil menciptakan suatu pengalaman yang berkesan kepada pelanggan yang makan di Rumah Makan Abeng 38. Hal ini dikarenakan pelanggan sering belum memperoleh kepuasan yang diharapkan seperti rumah makan yang dinilai pelanggan masih sempit dan sering tidak mampu menampung jumlah pelanggan yang mau makan disana, sirkulasi udara di rumah makan yang masih kurang baik sehingga pelanggan sering merasakan kepanasan, dan fasilitas berupa tempat parkir sering menjadi masalah terbesar, karena Rumah Makan Abeng 38 tidak memiliki tempat parkir tersendiri. Hal ini menyebabkan tidak terbentuknya suatu pengalaman yang positif dan berkesan di diri pelanggan sehingga perusahaan tidak mampu meningkatkan Loyalitas Pelanggan.

Selain itu, Kualitas Pelayanan yang diberikan Rumah Makan Abeng 38 belum optimal. Masalah yang terjadi pada Kualitas Pelayanan di perusahaan adalah pelanggan sering mengajukan komplain atas pelayanan yang diberikan seperti, lambatnya respon pegawai kepada pelanggan, tidak memberikan informasi mengenai rekomendasi menu sayuran kepada tamu, dan kurangnya pegawai dalam melayani tamu yang makan sehingga pelanggan sering kurang puas dan menjadi tidak loyal kepada perusahaan. Perusahaan perlu meningkatkan Loyalitas Pelanggannya agar pelanggan tidak beralih ke perusahaan lain dalam membeli produk. Loyalitas Pelanggan merupakan kesetiaan pelanggan terhadap perusahaan yang timbul tanpa paksaan melainkan dari kesadaran sendiri. Perusahaan yang mampu meningkatkan Loyalitas Pelanggan akan membuat perusahaan semakin berkembang dan mengurangi pengaruh serangan dari para kompetitor perusahaan sejenis. Loyalitas Pelanggan yang terbentuk dapat dipengaruhi oleh sejumlah faktor seperti Experiential Marketing dan Kualitas Pelayanan.

Experiential Marketing merupakan suatu konsep pemasaran yang bertujuan untuk membentuk pelanggan-pelanggan yang loyal dengan menyentuh emosi pelanggan dan memberikan suatu perasaan yang positif terhadap produk dan jasa yang ditawarkan 
perusahaan. Dalam pendekatan ini, perusahaan menciptakan produk atau jasa dengan menyentuh panca indra, hati, dan pikiran pelanggan. Produk dapat menyentuh nilai emosional pelanggan secara positif dapat menjadikan pengalaman yang berkesan antara perusahaan dengan pelanggan. Hal ini berpengaruh baik bagi perusahaan karena pelanggan yang puas senantiasa loyal dan akan kembali menggunakan produk atau jasa perusahaan serta memungkinkan pelanggan menceritakan pengalamannya menggunakan produk atau jasa kepada orang lain.

Berdasarkan wawancara awal dengan bagian penjualannya diketahui terjadi penurunan jumlah pelanggan yang makan di rumah makan tersebut. Untuk memperjelas permasalahan ini akan ditampilkan data jumlah pelanggan yang makan dan data penjualan di Rumah Makan Abeng 38 pada tahun 2014 sampai dengan tahun 2018 seperti pada Tabel 1.

Tabel 1. Uji Validitasi

\begin{tabular}{|l|c|c|c|}
\hline No. & Tahun & Jumlah Pelanggan (/BON) & Data Penjualan \\
\hline 1. & 2014 & 6323 & IDR 553,542,700 \\
\hline 2. & 2015 & 6229 & IDR 517,600,200 \\
\hline 3. & 2016 & 5985 & IDR 515,752,100 \\
\hline 4. & 2017 & 5924 & IDR 505,245,000 \\
\hline 5. & 2018 & 5894 & IDR 496,736,200 \\
\hline
\end{tabular}

Berdasarkan uraian di atas, dilakukan penelitian berjudul "Pengaruh Experiential Marketing Dan Kualitas Pelayanan Terhadap Loyalitas Pelanggan Rumah Makan Abeng 38".

\section{KAJIAN LITERATUR}

\subsection{Loyalitas Pelanggan}

Menurut Kotler dan Keller (2013:57), "Loyalitas (loyalty) pelanggan merupakan komitmen yang dipegang secara mendalam untuk membeli atau mendukung kembali produk dan jasa yang disukai di masa depan meski pengaruh situasi serta usaha pemasaran berpotensi menyebabkan pelanggan beralih". Menurut Hurriyati (2013:128), "Loyalitas merupakan suatu perilaku yang ditunjukan dengan pembelian rutin, didasarkan pada unit pengambilan keputusan".Menurut Hasan (2014:121) "Loyalitas pelanggan merupakan prilaku yang terkait dengan merek sebuah produk termasuk kemungkinan memperbaharui kontrak merek di masa yang akan datang dan berapa kemungkinan pelanggan untuk meningkatkan citra positif suatu produk".

Dari pengertian ini dapat disimpulkan bahwa loyalitas pelanggan merupakan perilaku pelanggan dalam komitmen, keyakinan dan kesetiaan terhadap merek produk serta merupakan tantangan manajemen terpenting karena dapat meningkatkan citra positif suatu produk. Pelanggan yang loyal pada merek tertentu cenderung terikat pada merek tersebut dan bakal membeli produk yang sama lagi sekalipun tersedia banyak alternatif lainnya. keuntungan dari adanya loyalitas pelanggan adalah berkurangnya pengaruh serangan dari para kompetitor dari perusahaan sejenis tidak hanya kompetisi dalam hal produk tetapi juga kompetisi dalam hal persepsi. Selain itu, konsumen yang loyal dapat mendorong perkembangan perusahaan karena mereka biasanya memberikan ide atau saran kepada perusahaan agar meningkatkan kualitas 
produknya dan pada akhirnya mereka tidak akan begitu mempermasalahkan harga karena mereka percaya pada produk serta kualitas yang dimiliki perusahaan. Menurut Hasan (2014:123) konsep pembentuk loyalitas pelanggan meliputi :

1) Konsep generik, loyalitas merek menunjukkan bahwa kecenderungan konsumen untuk membeli sebuah merek tertentu dengan tingkat konsistensi yang tinggi.

2) Konsep prilaku, pembelian ulang kerap kali dihubungkan dengan loyalitas merek (brand loyalty). Perbedaannya bila loyalitas merek mencerminkan komitmen psikologis terhadap merek tertentu sedangkan prilaku pembelian ulang menyangkut pembelian merek yang sama secara berulang-ulang.

3) Konsep pembelian ulang, merupakan hasil dominasi perusahaan (1) yang berhasil membuat produknya menjadi satu-satunya alternatif yang tersedia (2) yang terusmenerus melakukan promosi untuk memikat dan membujuk pelanggan membeli kembali merek yang sama.

Dengan demikian, loyalitas pelanggan dibentuk dari faktor konsep di atas seperti konsep generik, perilaku pelanggan dan pembelian ulang. Perusahaan perlu melihat dan mengatasi segala kebutuhan, harapan ataupun permasalahan yang dihadapi oleh pelanggan. Dengan perhatian itu pelanggan akan menjadi puas terhadap perusahaan dan melakukan transaksi ulang dengan perusahaan serta pada akhirnya mereka akan menjadi pelanggan perusahaan yang loyal. Semakin perusahaan menunjukkan bahwa perhatiannya maka akan semakin besar loyalitas pelanggan itu muncul.

\subsection{Experiential Marketing}

Menurut Oeyono dan Dharmayanti (2013:2) "Experiential marketing merupakan pengalaman yang merupakan peristiwa-peristiwa pribadi yang terjadi dikarenakan adanya stimulus tertentu (misalnya yang diberikan oleh pihak pemasar sebelum dan sesudah pembelian barang atau jasa)". Menurut Razanah (2013:2) “Experiential marketing (pengalaman) merupakan peristiwa pribadi yang terjadi pada respon terhadap rangsangan tertentu (misalnya, seperti yang telah disediakan oleh kegiatan pemasaran sebelum dan setelah pembelian)". Dari pengertian ini dapat disimpulkan bahwa experiential marketing merupakan pengalaman yang dirasakan konsumen atas peristiwa atau produk yang ditawarkan perusahaan yang dapat menyentuh hati dan perasaannya.

Menurut Oeyono dan Dharmayanti (2013:3) experiential marketing dapat diukur dengan menggunakan 5 faktor utama yaitu :

1) Sense / Sensory Experience.

Sense Experience didefinisikan sebagai usaha penciptaan pengalaman yang berkaitan dengan panca indera melalui penglihatan, suara, sentuhan, rasa, dan bau. Di mana digunakan untuk mendiferensiasikan perusahaan dan produknya di market, memotivasi konsumen untuk mau membeli produk tersebut dan menyampaikan value kepada konsumennya.

2) Feel / Affective Experience. 
Feel Experience adalah strategi dan implementasi untuk memberikan pengaruh merek kepada konsumen melalui komunikasi (iklan), produk (kemasan dan isinya), identitas produk (co-branding), lingkungan, website, orang yang menawarkan produk. Setiap perusahaan harus memiliki pemahaman yang jelas mengenai cara penciptaan perasaan melalui pengalaman konsumsi yang dapat menggerakkan imajinasi konsumen yang diharapkan dapat membuat keputusan untuk membeli. Tujuan dari Feel Experience adalah untuk menggerakkan stimulus emosional (events, agents, objects) sebagai bagian dari feel strategies sehingga dapat mempengaruhi emosi dan suasana hati konsumen.

3) Think / Creative Cognitive Experience.

Tujuannya adalah mendorong konsumen sehingga tertarik dan berpikir secara kreatif sehingga mungkin dapat menghasilkan evaluasi kembali mengenai perusahaan dan merek tersebut. Think Experience lebih mengacu pada future, focused, value, quality, serta growth dan dapat ditampilkan melalui inspirational, high technology, serta surprise.

4) Act / Physical Experience and Entitle Lifestyle.

Merupakan teknik pemasaran untuk menciptakan pengalaman konsumen yang berhubungan dengan tubuh secara fisik, pola perilaku, dan gaya hidup jangka panjang serta pengalaman yang terjadi dari interaksi dengan orang lain. Di mana gaya hidup sendiri merupakan pola perilaku individu dalam hidup yang direfleksikan dalam tindakan, minat, dan pendapat. Act Experience yang berupa gaya hidup dapat diterapkan dengan menggunakan trend yang sedang berlangsung atau mendorong terciptanya trend budaya baru. Tujuan dari Act Experience adalah untuk memberikan kesan terhadap pola perilaku dan gaya hidup, serta memperkaya pola interaksi sosial melalui strategi yang dilakukan.

Dengan demikian, pendekatan experiential marketing yang diterapkan perusahaan dapat diukur dari panca indera, perasaan, pikiran, tindakan, dan hubungan sosial sehingga dapat dijadikan indikator penelitian.

\subsection{Kualitas Pelayanan}

Menurut Tjiptono dan Chandra (2017:88) "Kualitas pelayanan adalah mencerminkan semua dimensi penawaran produk yang menghasilkan manfaat (benefits) bagi pelanggan”. Menurut Sangadji dan Sopiah (2013:99) "Kualitas layanan merupakan suatu kondisi dinamis yang berhubungan dengan produk, jasa, manusia, proses dan lingkungan yang memenuhi atau melebihi harapan". Dari pengertian ini dapat disimpulkan bahwa kualitas layanan merupakan kondisi yang berhubungan dengan produk, jasa, manusia, proses dan lingkungan dalam memuaskan kebutuhan dan menghasilkan manfaat bagi pelanggan.

Menurut Tjiptono dan Chandra (2012:178-180) faktor yang mempengaruhi kualitas layanan adalah :

1) Informasi, misalnya jalan/arah menuju tempat produsen, jadwal atau skedul penyampaian produk, harga, instruksi mengenai cara menggunakan produk inti atau layanan pelengkap, peringatan (warnings), persyaratan penjualan/layanan, 
pemberitahuan tentang adanya perubahan, dokumentasi, konfirmasi reservasi, rekapitulasi rekening, tanda terima, dan tiket.

2) Konsultasi, seperti pemberian saran, auditing, konseling pribadi, dan konsultasi manajemen/teknis.

3) Order taking, meliputi aplikasi (keanggotaan di klub atau program tertentu); order entry, dan reservasi (tempat duduk, meja, ruang, professional appointments, dan admisi untuk fasilitas yang terbatas seperti pameran).

4) Hospitality, di antaranya transportasi dan jasa keamanan.

5) Caretaking, terdiri dari perhatian dan perlindungan atas barang yang dibeli pelanggan.

6) Exceptions, meliputi permintaan khusus sebelum penyampaian produk, menangani komplain/pujian/saran, penyelesaian masalah (jaminan dan garansi atas kegagalan pemakaian produk; kesulitan yang muncul dalam pemakaian produk; kesulitan yang disebabkan kegagalan produk, termasuk masalah dengan staf atau pelanggan lainnya); dan restitusi (pengambilan uang, kompensasi atau ganti rugi, dan sebagainya).

7) Billing, meliputi faktur untuk transaksi individual.

\section{METODE PENELITIAN}

Penelitian dilakukan di Rumah Makan Abeng 38 yang berlokasi di Jalan Bawean No. 38 Gang Buntu, Medan. Waktu penelitian direncanakan dari bulan April 2019 sampai dengan Juli 2019. Menurut Sugiyono (2015:8), ”jenis penelitian deskriptif kuantitatif adalah metode penelitian yang berdasarkan filsafat positivisme, digunakan untuk meneliti pada populasi atau sampel tertentu, pengumpulan data menggunakan instrumen penelitian, analisis data bersifat kuantitatif atau statistik dengan tujuan untuk menguji hipotesis yang telah ditetapkan." Populasi dalam penelitian ini adalah pelanggan yang makan di Rumah Makan Abeng 38 pada tahun 2018 sebanyak 5894 pelanggan. sampel dalam penelitian ini adalah 98 responden.

\subsection{Analisis Regresi Linier Berganda}

Menurut Ghozali (2016:94), analisis regresi digunakan untuk mengukur kekuatan hubungan antara dua variabel atau lebih, juga menunjukan arah hubungan antara variabel dependen dengan independen. Model analisis data yang digunakan dalam penelitian ini adalah analisis regresi linear berganda untuk mengetahui seberapa besar pengaruh experiential marketing dan kepuasan pelanggan terhadap loyalitas pelanggan rumah makan abeng 38 . Analisis ini bantuan perangkat lunak SPSS versi 23 dengan rumus:

$$
\mathrm{Y}=\alpha+\beta 1 \mathrm{X} 1+\beta 2 \mathrm{X} 2+\mathrm{e}
$$

Keterangan :

$\mathrm{Y}=$ Loyalitas Pelayanan (dependent variabel)

$\mathrm{X} 1=$ Experiential Marketing (independent variabel)

X2 = Kualitas Pelayanan (independent variabel)

$\alpha \quad=$ konstanta

$\beta 1=$ koefisien untuk variabel experiential marketing

$\beta 2=$ koefisien untuk variabel kualitas pelayanan

e $\quad=$ persentase kesalahan $(10 \%)$ 


\section{HASIL}

\subsection{Uji Validitas}

Uji validitasdilakukan pada pelanggan Rumah Makan Abeng 38. Degree of freedom (df) yang digunakan adalah 30-2 = 28 dengan alpha sebesar 5\% sehingga nilai rtabel (uji dua sisi) sebesar 0,361.Untuk nilai rhitung dapat dilihat dari nilai Pearson Correlation di uji validitas. Hasil uji validitas untuk variabel dalam penelitian ini yaitu:

Tabel 2. Hasil Uji Validitas Faktor Analisis Experiential Marketing

\begin{tabular}{|l|l|l|l|}
\hline Pernyataan & Nilai $\mathbf{r}_{\text {hitung }}$ & Nilai $\mathbf{r}_{\text {tabel }}$ & Keterangan \\
\hline Experiential Marketing $\left(\mathbf{X}_{\mathbf{1}}\right)$ & & & \\
\hline $\begin{array}{l}\text { Rumah Makan Abeng 38 memiliki aroma } \\
\text { masakan yang mampu meningkatkan selera anda }\end{array}$ & 0,766 & 0,361 & Valid \\
\hline $\begin{array}{l}\text { Rumah Makan Abeng 38 memiliki desain } \\
\text { ruangan yang menarik }\end{array}$ & 0,719 & 0,361 & Valid \\
\hline $\begin{array}{l}\text { Rumah Makan Abeng 38 telah dikenal oleh } \\
\text { masyarakat luas }\end{array}$ & 0,736 & 0,361 & Valid \\
\hline $\begin{array}{l}\text { Rumah Makan Abeng 38 adalah salah satu } \\
\text { pilihan terbaik untuk pelanggan yang } \\
\text { mengutamakan cita rasa, pelayanan, dan harga }\end{array}$ & 0,794 & 0,361 & Valid \\
\hline
\end{tabular}

Sumber :Hasil Penelitian, 2019 (Data diolah)

Berdasarkan Tabel 2 dengan degree of freedom yang digunakan adalah $(30-2=28)$ menunjukan pernyataan untuk variabel Experiential Marketing $\left(\mathrm{X}_{1}\right)$ memiliki $\mathrm{r}_{\text {hitung }}>\mathrm{r}_{\text {tabel }}$ sehingga data disimpulkan bahwa semua pernyataan untuk variabel Experiential Marketing dinyatakan valid.

Tabel 3. Hasil Uji Validitas Faktor Analisis

Kualitas Pelayanan

\begin{tabular}{|l|c|c|c|}
\hline Pernyataan & Nilai $\mathbf{r}_{\text {hitung }}$ & Nilai $\mathbf{r}_{\text {tabel }}$ & Keterangan \\
\hline $\begin{array}{l}\text { Rumah Makan Abeng 38 dapat menyiapkan } \\
\text { makanan sesuai yang Anda pesan }\end{array}$ & 0,919 & 0,361 & Valid \\
\hline $\begin{array}{l}\text { Rumah Makan Abeng 38 memiliki pegawai yang } \\
\text { senantiasa memberikan bantuan dengan cepat } \\
\text { kepada Anda ketika diperlukan }\end{array}$ & 0,680 & 0,361 & Valid \\
\hline $\begin{array}{l}\text { Rumah Makan Abeng 38 telah mengutamakan } \\
\text { kebersihan dan higenis makanan yang dijual } \\
\text { kepada pelanggannya }\end{array}$ & 0,881 & 0,361 & Valid \\
\hline $\begin{array}{l}\text { Rumah Makan Abeng 38 telah melayani Anda } \\
\text { dengan sopan }\end{array}$ & 0,876 & 0,361 & Valid \\
\hline
\end{tabular}

Sumber :Hasil Penelitian, 2019 (Data diolah) 
Berdasarkan Tabel 4.5 dengan degree of freedom yang digunakan adalah $(30-2=28)$ menunjukkan pernyataan untuk variabel Kualitas Pelayanan (X2) memiliki rhitung >rtabel sehingga data disimpulkan bahwa semua pernyataan untuk variabel Kualitas Pelayanan dinyatakan valid.

\subsection{Uji Reliabilitas}

Suatu alat pengukur dikatakan reliabel bila alat itu dalam mengukur sesuatu gejala pada waktu yang berlainan senantiasa menujukkan hasil yang sama. Metode uji reliabilitas yang sering digunakan adalah Cronbach's Alpha. Menurut Ghozali (2013:48), metode uji reliabilitas yang sering digunakan adalah Cronbach's Alpha. Pengambilan keputusan untuk uji reliabilitas sebagai berikut:

1) Cronbach's Alpha $<0,6 \quad=$ reliabilitas buruk

2) Cronbach's Alpha 0,6-0,79= reliabilitas diterima

3) Cronbach's Alpha $0,8 \quad$ = reliabilitas baik

Hasil uji reliabilitas terhadap variabel yang digunakan dalam penelitian adalah:

Tabel 4. Uji Reliabilitas Experiential Marketing

Reliability Statistics

\begin{tabular}{|r|r|}
\hline Cronbach's Alpha & N of Items \\
\hline .728 & 4 \\
\hline
\end{tabular}

Sumber : Hasil Olah Data, 2019

Berdasarkan Tabel 4.7 dengan degree of freedom yang digunakan adalah $(30-2=28)$ menunjukkan nilai Cronbach's Alpha lebih besar dari 0.6 sehingga semua pernyataan Experiential Marketing dinyatakan telah reliabel.

Tabel 5. Uji Reliabilitas Kualitas Pelayanan

\begin{tabular}{|r|r|}
\hline Cronbach's Alpha & N of Items \\
\hline .854 & 4 \\
\hline
\end{tabular}

Sumber : Hasil Olah Data 2019,

Berdasarkan Tabel 4.8, dengan degree of freedom yang digunakan adalah $(30-2=28)$ menunjukkan nilai Cronbach's Alpha lebih besar dari 0.6 sehingga semua pernyataan Kualitas Pelayanan dinyatakan telah reliabel.

Tabel 6. Uji Reliabilitas Loyalitas Pelanggan 


\begin{tabular}{|r|r|}
\hline $\begin{array}{c}\text { Cronbach's } \\
\text { Alpha }\end{array}$ & N of Items \\
\hline .838 & 3 \\
\hline
\end{tabular}

Berdasarkan Tabel 4.9 dengan degree of freedom yang digunakan adalah $(30-2=28)$ menunjukkan nilai Cronbach's Alpha lebih besar dari 0.6 sehingga semua butir pernyataan Loyalitas Pelanggan dinyatakan telah reliabel.

\subsection{Analisis Regresi Berganda}

Hasil pengujian analisis regresi berganda dapat dilihat pada Tabel 7:

Tabel 7. Hasil Analisis Regresi Berganda

Coefficients $^{\mathrm{a}}$

\begin{tabular}{|c|c|c|c|c|c|c|}
\hline \multirow{2}{*}{\multicolumn{2}{|c|}{ Model }} & \multicolumn{2}{|c|}{ Unstandardized Coefficients } & \multirow{2}{*}{$\begin{array}{c}\begin{array}{c}\text { Standardized } \\
\text { Coefficients }\end{array} \\
\text { Beta }\end{array}$} & \multirow[b]{2}{*}{$\mathrm{t}$} & \multirow[b]{2}{*}{ Sig. } \\
\hline & & $\mathrm{B}$ & Std. Error & & & \\
\hline \multirow[t]{3}{*}{1} & (Constant) & 1.812 & .609 & & 2.975 & .004 \\
\hline & Experiental_Marketing & .178 & .062 & .240 & 2.886 & .005 \\
\hline & Kualitas_Pelayanan & .419 & .062 & .565 & 6.776 & .000 \\
\hline
\end{tabular}

Berdasarkan tabel 4.12.di atas, diperoleh persamaan regresi linear berganda seperti berikut:

\section{LoyalitasPelanggan $=1,812+0,178$ ExperienMarket $+0,419$ KualiPelaya $+\mathrm{e}$}

Penjelasan analisis regresi linear berganda diatas adalah :

1. Konstanta sebesar 1,812 artinya apabila nilai Experiential Marketing dan Kualitas Pelayanan bernilai 0 atau tidak ada, maka Loyalitas Pelanggan pada perusahaan tersebut bernilai 1,812 .

2. Koefisien $\mathrm{X}_{1}$ senilai 0,178 bernilai positif, artinya Experiential Marketing mempunyai hubungan positif dengan Loyalitas Pelanggan. Apabila Experiential Marketing meningkat 1\%, maka Loyalitas Pelangganakan meningkat sebesar 0,178 satuan. Artinya, semakin tinggi Experiential Marketing maka semakin meningkat Loyalitas Pelanggan pada perusahaan.

3. Koefisien $\mathrm{X}_{2}$ senilai 0,419 bernilai positif, artinya Kualitas Pelayanan mempunyai hubungan positif dengan Loyalitas Pelanggan. Apabila Kualitas Pelayanan meningkat 1\%, maka Loyalitas Pelangganakan meningkat sebesar 
0,419 satuan. Artinya, semakin tinggi Kualitas Pelayanan maka semakin meningkat Loyalitas Pelanggan pada perusahaan.

\section{SIMPULAN}

Hasil dari penelitian ini menyatakan pengaruh Experiential Marketing (X1) dan Kualitas Pelayanan (X2) terhadap Loyalitas Pelanggan (Y) ditunjukkan dari hasil Loyalitas Pelanggan $=1,812+0,178$ Experiential Marketing + 0,419 Kualitas Pelayanan + e. Hal ini memberikan arti bahwa variabel Experiential Marketing dan Kualiatas Pelayanan secara bersama-sama mempunyai pengaruh yang positif terhadap Loyalitas Pelanggan. Hasil Uji t menunjukkan bahwa Experiential Marketing secara parsial memiliki pengaruh positif dan signifikan terhadap Loyalitas Pelanggan pada Rumah Makan Abeng 38 karena nilai thitung sebesar 2,886 lebih besar dari ttabel 1,985. Hasil Uji t menunjukkan bahwa Kualitas Pelayanan secara parsial memiliki pengaruh positif dan signifikan terhadap Loyalitas Pelanggan pada Rumah Makan Abeng 38 karena nilai thitung sebesar 6,776 lebih besar dari ttabel 1,985. Hasil Uji F menunjukkan bahwa Experiential Marketing dan Kualitas Pelayanan secara serempak berpengaruh terhadap Loyalitas Pelanggan pada Rumah Makan Abeng 38 karena nilai Fhitung sebesar 50,808 lebih besar dari Ftabel yang sebesar 3,09.

\section{DAFTAR PUSTAKA}

Abdullah, Thamrin dan Tantri, Francis. 2014. Manajemen Pemasaran. Dep: Raja Grafindo Persada.

Ghozali, Imam. 2016. Aplikasi Analisis Multivariat dengan Program IBM SPSS 23. Edisi Kedelapan. Semarang: Badan Penerbit Universitas Diponegoro.

Hasan, Ali. 2014. Marketing dan Kasus-Kasus Pilihan. PT Indeks. Jakarta.

Hurriyati, Ratih. 2013. Bauran Pemasaran dan Loyalitas Konsumen. Bandung: Alfabetha.

Irjayanti, Endah, Johny Revo Elia Tampi, dan Danny David Samuel Mukuan. 2018. Pengaruh Kualitas Pelayanan Terhadap Loyalitas Pelanggan pada Klinik Esther House of Beauty Manado (Studi Kasus Pada Pelanggan Klinik Esther House of Beauty Manado). Jurnal Administrasi Bisnis. Volume 6 No. 2 Tahun 2018.

Kotler, Philip dan Kevin Lane Keller. 2013. Manajemen Pemasaran. Edisi-13. Jilid-2. Penerjemah Bob Sabran. Jakarta: Erlangga.

Marina, Sandriana, Andi Darmawati, dan Indra Setiawan. 2014. Pengaruh Kualitas Pelayanan Terhadap Loyalitas Pelanggan pada Perusahaan Penerbangan Full Service Airlines. Jurnal Manajemen Transportasi \& Logistik (JMTransLog). Volume 1 No. 2 Tahun 2014.

Oeyono, Januar T. dan Diah Dharmayanti. 2013. Analisa Pengaruh Experiential Marketing Terhadap Loyalitas Konsumen Melalui Kepuasan Sebagai Intervening Variabel di 
Tator Café Surabaya Town Square. Jurnal Manajemen Pemasaran. Volume 1 No. 2 Tahun 2013.

Razanah, Zahrina, Srikandi Kumadji, dan Andriani Kusumawati. 2013. Penerapan Experiential Marketing Strategy dan Pengaruhnya Terhadap Kepuasan dan Loyalitas (Studi pada Pelanggan Bakso Cak Kar Singosari - Malang). Jurnal Administrasi Bisnis (JAB). Volume 13 No. 3 Tahun 2013.

Sangadji, Etta Mamang dan Sopiah. 2013. Perilaku Konsumen: Pendekatan Praktis Disertai Himpunan Jurnal Penelitian. Yogyakarta: CV. Andi Offset.

Saraswati, Riza, Zainul Arifin, dan Edy Yulianto. 2013. Pengaruh Experiential Marketing Terhadap Loyalitas (Studi pada Pelanggan Taman Indie Resto Malang). Jurnal Administrasi Bisnis (JAB). Volume 6 No. 1 Tahun 2013.

Suchaeri, Heri. 2012. Total Customer Percepatan Laba Sepanjang Masa. Solo: PT Tiga Serangkai Pustaka Mandiri.

Sudaryono. 2018. Manajemen Pemasaran Teori dan Implementasi. Edisi Kesatu. Andi. Yogyakarta.

Sugiyono. 2015. Metode Penelitian Kuantitatif, Kualitatif dan R\&D. Bandung. Alfabeta.

Tjiptono. 2014. Pemasaran Jasa: Prinsip, Penerapan, dan Penelitian. Edisi Kesatu. Andi. Yogyakarta.

Tjiptono, Ferry dan Gregorius Chandra. 2012. Pemasaran Strategik. Edisi-II. Yogyakarta: Andi.

Tjiptono, Ferry dan Gregorius Chandra. 2017. Pemasaran Strategik. Edisi-III. Yogyakarta: Andi. 